\title{
CONTEXT OF SCIENTIFIC AND INSTITUTIONAL RENEWAL IN ISLAMIC HIGHER EDUCATION (PTKI): A Study On Azyumardi Azra's Thought 1998-2015
}

\author{
Iswantir M \\ Tarbiyah Faculty, State Institute for Islamic Studies (IAIN) Bukittinggi \\ Jl. Gurun Aur Kubang Putih Kabupaten Agam, West Sumatera, Indonesia \\ E-mail: iswantir1976@yahoo.com
}

\begin{abstract}
Context of Scientific and Institutional Renewal in Islamic Higher Education (PTKI): A Study on Azyumardi Azra's Thought 1998-2015. The practice of modernization of Islamic education has been demonstrated by Azyumardi Azra at State Islamic University (UIN) of Jakarta. The type of the research used is the study of thinking figures, which is called a research figure or an individual life history. This type of the research is classified as qualitative research. The focus of this research is to identify Azra's thoughts in the context of intellectual thinking and institutional perspective in renewing Islamic thoughts in Indonesia. This study uses primary and secondary data sources. The primary data source is a character that became the object of research, because the character is still alive, and then the primary data source in this study is Azyumardi Azra and his work. The other complement data is taken from books, papers, and journals. The result of the research indicated that the context of intellectual thinking and institutional perspectives of Azra in the renewal of Islamic thoughts in Indonesia has the same mission, namely to eliminate the scientific dichotomy in the development of PTKI. A scientific development with integrative paradigm requires an institutional transformation of State Islamic Collage (STAIN) or State Institute for Islamic Studies (IAIN) into State Islamic Universiy (UIN).
\end{abstract}

Keywords: Azyumardi Azra; renewals context of thought; integrated science; PTKI

\begin{abstract}
Abstrak: Konteks Pembaharuan Keilmuan dan Kelembagaan dalam Perguruan Tinggi Keagamaan Islam (PTKI): Studi Pemikiran Azyumardi Azra 1998-2015. Praktik pembaharuan keilmuan dan kelembagaan Perguruan Tinggi Keagamaan Islam dilakukan oleh Azyumardi Azra terhadap Universitas Islam Negeri (UIN) Jakarta. Fokus penelitian ini adalah menelaah pemikiran Azyumardi Azra, yakni tentang konteks pembaharuan keilmuan dan kelembagaan dalam Perguruan Tinggi Keagamaan Islam (PTKI). Penelitian ini menggunakan sumber data primer dan sekunder. Sumber data primer adalah tokoh yang menjadi objek penelitian, kerena tokohnya masih hidup, maka yang menjadi sumber data primer dalam penelitian ini adalah Azyumardi Azra dan hasil karyanya. Sumber data pendukung adalah buku, makalah, dokumentasi tentang Azra. Hasil penelitian menemukan bahwa pemikiran Azyumari Azra tentang konteks pembaharuan keilmuan dan kelembagaan dalam PTKI memiliki misi yang sama, yakni ingin menghilangkan dikotomi keilmuan dalam pengembangan keilmuan PTKI, dengan membangun paradigma keilmuan yang bersifat integratif. Pengembangan keilmuan dengan paradigma integratif mengharuskan perlu perubahan kelembagaan dari bentuk Institut Agama Islam Negeri (IAIN) atau Sekolah Tinggi Agama Islam Negeri (STAIN) menjadi Universitas Islam Negeri (UIN).
\end{abstract}

Kata kunci: Azyumardi Azra; konteks pembaharuan pemikiran; integrasi ilmu; PTKI

\section{Introduction}

The 1998 reformation was a greatly valuable momentum for Azyumardi Azra (hereinafter referred to as Azra) to realize his brilliant thoughts about Islamic institutions. As a public figure, Azra began to rise and become viral coloring
Islamic dialogues on Indonesian television. While still serving as the Rector Assistant for the Academic Affairs of the Syarif Hidayatullah State Islamic Institute in Jakarta, he accompanied students several times demonstrating to the People's Representative Council (DPR) / People's 
Consultative Assembly (MPR) building, becoming a speaker for printed and electronic media, and diligently giving opinions on politics, democracy, consolidating democracy, and conflicts communal like in Ambon and Poso. He also diligently fulfilled invitations to seminars and various training on peace. His face often appeared on television, both in the form of short quotes and talk. He became widely known. ${ }^{1}$ Azra is also a figure of renewal in Islamic education. One of the modernizations of Islamic education carried out by Azra was to make changes to the State Institute for Islamic Studies (IAIN) of Jakarta to become the State Islamic University (UIN) of Jakarta.

According to Azra, there are seven problems that become the role of mentality and morality in Islamic higher education institutions, namely (1) the direction of education has eliminated its objectivity, (2) the process of self-maturation does not take place, (3) the process of education in tertiary institutions deeply restrains students and even lecturers, (4) the burden of the curriculum is so heavy, and even worse, almost entirely oriented to the development of mere cognitive domains, (5) some subjectsincluding religious subjects-are delivered in verbal form which is also accompanied by rotememorizing, (6) at the same time, students are faced with values that are often contradictory, and (7) students also have difficulties in finding exemplary examples that are good in their environment. $^{2}$

Until now, there are still complaints against the IAIN, both from IAIN itself and from the general public, namely complaints about the education process and IAIN output. On the one hand, complaints or precisely criticism is a natural thing, and even needed to encourage the innovation process and continuous improvement of the existence of IAIN so as its presence becomes more meaningful. Some complaints about the IAIN relate to weaknesses in language skills, system weaknesses and methods, weakness

\footnotetext{
1 Andina Dwifatma, Cerita Azra: Biografi Cendikiawan Muslim Azyumardi Azra, (Jakarta: Erlangga, 2011), p. 195

2 Azyumardi Azra, Paradigma Baru Pendidikan Nasional Rekonstruksi dan Demokratisasi, (Jakarta: Kompas, 2002), p. xi
}

of mental attitude, and lack of hardware. ${ }^{3}$ To overcome this problem, IAIN development is needed. This concept provides an opportunity for IAIN to develop various sciences and efforts to prepare for changes in IAIN to UIN.

Azra, through UIN Jakarta, has succeeded in changing the image of Islamic religious higher education as a university that is on par with universities under the auspices of the Ministry of National Education (Ministry of Technology Research and Higher Education now). ${ }^{4}$ Azra is also able to bring Islamic universities, especially UIN Jakarta, into the best campus, not only at the national level, but at the international level. Azra is a breakthrough figure against negative views on Islamic higher education so far. As a result, he was able to turn the campus into a proud Islamic university.

The scientific and institutional renewal of the Islamic Higher Education (PTKI) does not only become a discourse, but must become a reality and be practiced. This practice has been seen in various efforts to renew Azra which he did with UIN Jakarta. In this context, it can be said that Azra is not only a theoretical thinker about Islamic education, but also as a praxis about Islamic education. For Azra, it seems that ideas and reality must be built together because in this way an idea can be felt to benefit. By taking a simple example, it seems that he wants between soul and body, body and spirit, world and the hereafter, science and religion, and various other equilibrium as emphasized in Islamic teachings can be a reality that benefits. ${ }^{5}$ Actually, the reverberation of the modernization of Islamic education in Indonesia had begun in the early 2oth century. Initially, the renewal echo was brought by Indonesian students studying in the Middle East back to Indonesia. In this regard, several figures emerged to reform Islamic thought in Indonesia. The reformers are mostly engaged in social organization, education and politics. ${ }^{6}$ Azra, is one of the leaders in reforming

\footnotetext{
${ }^{3}$ Azyumardi Azra, Esai-Esai Intelektual Muslim \& Pendidikan Islam, (Jakarta: Logos, 1999), pp. 125-128

4 Abuddin Nata,Tokoh-tokoh Pembaharuan Pendidikan Islam di Indonesia, (Jakarta: Raja Grafindo Persada), p. 392

${ }^{5}$ Abuddin Nata,Tokoh-tokoh Pembaharuan..., p. 107

${ }^{6}$ Haidar Putra Daulay, Dinamika Pendidikan Islam di Asia
} 
Islamic education in Indonesia, especially with the success of transforming IAIN to UIN.

Among the most important factors causing PTKI's institutional growth is the expansion of santri/students through education. It must be admitted, that Indonesian Muslims generally only have very limited access to the Dutch colonial education system. But having achieved the independence, Muslims gained wider opportunities to obtain education. The wider opportunity began to actually materialize, especially since the late 1950 s with the establishment of state universities, and more specifically Islamic higher education.?

According to Azra, the aspirations of Muslims to form Islamic tertiary institutions are generally driven by three objectives, namely (1) to carry out the study and development of Islamic sciences at a higher level in a more systematic and directed manner; (2) to develop and increase Islamic dakwah so that Islam is better understood and implemented by students and Muslims in general, and (3) to reproduce and regenerate other religious scholars and functionaries, both in state bureaucracies, such as the Ministry of Religion, and social institutions, dakwah and private Islamic education. The consequences of the aspirations mentioned above are as social expectations and academic expectations. The aim is Islamic tertiary institutions, especially IAINs to assume multiple roles; academics, and da'wah (preaching) ${ }^{8}$.

From the background above, the study of this researcher tries to focus on the Azyumardi Azra' thought 1998-2015 regarding the context of scientific and institutional renewal in the Islamic Religious College. Azra is indeed one of the most popular Indonesian Muslim scholars and is a productive person in writing, both in the fields of education, history, Islamic thought, research, and studies related to politics. Therefore, one thing that cannot be denied is the large amount of research and studies on Azra's thought from

\footnotetext{
Tenggara, (Jakarta: Rineka Cipta, 2009), p. 30

${ }^{7}$ Azyumardi Azra, Konteks Berteologi di Indonesia, (Jakarta: Paramadina, 1999), p. 189

${ }^{8}$ Azyumardi Azra, Pendidikan Islam Tradisi dan Modernisasi Menuju Milenium Baru,(Jakarta: Logos, 1999), p. 170
}

various perspectives, but more commonly found in S-1 (undergraduate) and S-2 (post graduate) research. While the research that discusses Azra's thought as the research study has not been found.

\section{Method}

This research is a study of the character's thoughts or one's life history (individual life history). This type of research is one type of qualitative research ${ }^{9}$. The study of the characters in this study used narrative research, namely the design of research on humanity that studied the lives of individuals to tell their lives.This information is then retold by the researcher in narrative chronology ${ }^{10}$. Narrative research has many forms. It uses a variety of analytical practices, and is rooted in a variety of social and humanities disciplines. As a method, this narrative research begins with experiences expressed in the stories conveyed by individuals ${ }^{11}$. The data source in this study uses primary and secondary data sources. Primary sources are figures who are the object of the research. Because the figures in this study are still alive, the primary data sources in this study are Azra and the results of his work.

\section{Intellectual Biography of Azyumardi Azra Academic Career of Azyumardi Azra}

Azra was born in Lubuk Alung, an area in the center of the sub-district in Padang Pariaman on the edge of the Bukittinggi-Padang highway in West Sumatra, on March 4, 1955. Azyumardi Azra is a name taken from Arabic which means quite poetic, namely 'green gem', although he would only know this many years later, from an Iranian professor whom he met at a conference abroad. ${ }^{12}$ Azra's basic education starts from the

${ }_{9}$ Arif Furchan dan Agus Maimun, Studi Tokoh: Metode Penelitian Mengenai Tokoh, (Yogyakarta: Pustaka Pelajar, 2005), p. 1

${ }_{10}$ John W. Creswell, Research Design Pendekatan Metode Kualilatif, Kuantitatif, dan Campuran, (Yogyakarta: Pustaka Pelajar, 2016), p. 18

"John W. Creswell, Penelitian Kualitatif \& Desain Riset: Memilih Di Antara Lima Pendekatan, (Yokyakarta: Pustaka Pelajar, 2015), p. 96

12 Andina Dwifatma,Cerita Azra: Biografi Cendikiawan Muslim...., p. 1 
elementary school near his house. After that, he continued to the State Religion Teacher Education School (PGAN) Padang. After graduating from PGAN in 1975, his father wanted Azra to study at IAIN Padang, but Azra was not interested. He wanted to study at the Institute of Teacher Training and Education (IKIP) or study history at Andalas University Padang (UNAND). But his parents still wanted Azra to determine his attitude, namely studying at IAIN in Jakarta. ${ }^{13}$ In 1976, officially Azra was listed as a student at the Syarif Hidayatullah Tarbiyah Faculty of IAIN Ciputat in the Arabic Language Department. He chose this department as a provision if one day he succeeded in continuing his studies in Egypt. "At that time, my role model was Buya Hamka and I really wanted to be like him, including the way of his life which is going to school to Egypt," he said. ${ }^{14}$

Then through the Columbia University President Fellowship program, Azra continued her studies at the Department of History at the same university and studied history there. Through this department, he obtained his second MA degree in 1989 and added the M. Phil degree in 1999 in the field of history. Finally, from this history department, Azra obtained his Ph.D. two years later, precisely in 1992. To complete his S3 program, Azra wrote a dissertation which later became one of the original great thoughts he produced. The title of the dissertation is "The Transmission of Islamic Reformism to Indonesia: Networks of Middle Eastern and Malay Indonesian Ulama in the Seventeenth and Eighteen Centuries". We carry two MA titles, one M. Phil, and one Ph.D. Azra was still enthusiastic about leaving again to post a postdoctoral program at Oxford University for one year (1995-1996). At IAIN Jakarta, in addition to being an Editor in Chief of the Journal of Islamic Studies, Azra was also entrusted with the responsibility of being Deputy Director of the Center for the Study of Islam and Society (PPIM) IAIN Jakarta until 1997. After that, Azra's academic and scientific careers increased with

\footnotetext{
${ }^{13}$ Abuddin Nata, Tokoh-tokoh Pembaharuan..., p. 393

14 Andina Dwifatma, Cerita Azra: Biografi Cendikiawan Muslim..., p. 12
}

more writing which he conveyed on various occasions seminar forums, both inside and outside the country. Along with the changes in national leadership, where Quraish Shihab was appointed as Minister of Religion, without any obstacles Azra was appointed to be a Rector of Syarif Hidayatullah IAIN Jakarta (1998-2002), Rector of UIN Syarif Hidayatullah (2002-2006), and Director of the Syarif Hidayatullah UIN School Jakarta (2006-2015)..$^{15}$

\section{Azyumardi Azra's works}

Azra is an active and productive Muslim scholar in expressing his thoughts. His writings or articles are often found in various newspapers, journals, and other scientific magazines. Until now more than thirteen of his books have been published and some of them have been translated into Arabic and English.

The world of writing has been occupied by Azra since 1978 when he was a student at the Syarif Hidayatullah IAIN in Jakarta, starting from the habit of writing poems and short stories in Indonesian and English. His poems were often published in the Indonesian Times and Panji Masyarakat magazine. Then since students, Azra became more intensive in writing because she also worked as a journalist who always wrote reports.

In addition, he also actively writes analytical and interpretative articles that are often published in Merdeka and Kompas newspapers. Furthermore, when acting as a lecturer at his alma mater, the tradition of writing was increasingly developed. Azra's articles published internationally are; (a) "Education, Law, Mysticism: Constructing Social Realities", in Mohd. Thayib Osman (ed), Islamic Civilization in Malay World, Kuala Lumpur \& Istanbul: Language Council and Pustidaka \& IRCICA, 1997, (b) "A Hadhrami Religious Scholar in Indonesia: Sayyad Uthman", in U. Freitag \& W.G. Clarence-Smith (ed), Hadhrami Traders, Scholars, and Statement in the Indian Ocean 1950-1960, Leiden: E.J. Brill, 1997, (c) “Opposition to Sufism in the East Indies in the Eighth and Eighteenth Centuries", in Frederick de Jong \& Bernd Redthe

${ }^{15}$ Abuddin Nata,Tokoh-tokoh Pembaharuan..., pp. 395-397 
(ed), Islamic Mysticism Contested: Thirteenth Centuries of Controversies and Polemics, Leiden: Brill, 1999 and (d) "The Islamic Factor in the PostSoeharto Indonesia", in Chris Manning \& Peter van Diermen (ed), Indonesia in Transition: Social Aspects of Reformation and Crisis, Singapore: RSPAS-ANU \& ISEAS, 2000.

Azra wrote books in English, namely (a) Islam in Indonesia: Continuity and Changes in Modern World, (b) Islam in Malay-Indonesian World, and (c)) Islam, Ulama and the State System. Each of these books is 300 pages thick. In addition, Azra has also edited and translated several books, including: 1). Islam and Social Issues, (Pustidaka Panjimas, 1983), 2). Modern Development in Islam, (Indonesian Torch Foundation, 1985), 3). Islamic perspective in Southeast Asia, (Indonesian Torch Foundation, 1984). There are also translation works: Know the Doctrines of the Sufis, (Pustidaka Jaya, 1984), and Religion in the Middle of Secularization of Politics, (Pustidaka Panjimas, 1985).

Azra also wrote a book from his dissertation, namely the Middle East Ulama Network and the Archipelago Islands XVII and XVIII Ages, (Bandung: Mizan, 1994) and Islamic Political Upheaval, (Jakarta: Paramadina, 1996). In 1999, Azra published five new books at once, namely: (a) Islamic Education: Tradition and Modernization Towards the New Millennium, (Logos, Jakarta), (b) Muslim Intellectuals \& Islamic Education, (Logos, Jakarta), (c) Theological context in Indonesia: Islamic experience, (Jakarta: Paramadina), (d) Towards Civil Society: Ideas, Facts and Challenges, (Bandung: Rosdakarya) and (e) Southeast Asian Islamic Renaissance: History of Discourse \& Power, (Bandung: Rosdakarya). In 2000, Azra also published a book titled Substantive Islam: So that People Don't Become Frothy, (Bandung: Mizan). In 2002, Azra published and launched its latest books, as follows: Contemporary Islamic Historiography: Discourse, Actuality and Historical Actors (PT. Gramedia Pustidaka Utama), New Paradigm of National Education: Reconstruction and Democratization; Reposition of Religion and State Relations: Knitting Inter-Community Harmony (Kompas Book Publishers), Reaching Solidarity:
Tension between Democracy, Fundamentalism and Humanism (Pustidaka Panjimas), New Conflict between Civilizations: Globalization, Radicalism, Plurality; Islam Nusantara: Global and Local Networks (Bandung: Mizan) which are translated from English-language papers. In 2003, Azra also wrote a book entitled "Surau: Traditional Islamic Education in Transition and Modernization".

Besides that, Azra also often wrote foreword for books written by other people and contributed writings to several books of writing. This shows that in his busy life as chancellor, Azra is still very productive in writing, besides actively attending various seminars, both national and international. As he admitted, writing for Azra is a must. He used to write at any time, not depending on his writing mood. In fact, he said, he could write in a car or on an airplane. When he was Chancellor of IAIN Jakarta, Azra provided a special time for writing, which was around dawn. Woke up at 3:00 a.m., then wrote until 7:00 a.m. only interspersed with Fajr prayer.

The world of writing has been occupied by Azra since 1978, starting from the habit of writing poems and short stories in Indonesian and English. His poems are often published in the Indonesian Times and Panji Masyarakat magazine. Then since Azra's students became more intensive in writing, because he also worked as a journalist who always wrote reports. In addition, he also actively writes analytical and interpretative articles which are often published in Merdeka and Kompas newspapers. Furthermore, when he worked as a lecturer at his alma mater, he developed the tradition of writing. The books were Islam and Social Issues, (Jakarta, Pustidaka Panjimas, 1983), Islamic Perspective in Southeast Asia, (Jakarta, Indonesian Torch Foundation , 1984), Understanding Sufi Teachings, (Jakarta, Pustidaka Jaya, 1984), Modern Development in Islam, (Jakarta, Indonesian Torch Foundation, 1985), Religion in Political Secularism, (Jakarta, Pustidaka Panjimas, 1985), Substantive Islam; in order for the Ummah not to be exhausted, (Bandung, Mizan, 2000), Islamic political upheaval from Fundamentalism, Modernism to Post Modernism, (Jakarta, Paramadina, 1996), 
Surau Traditional Islamic Education in Transition and Modernization, (Jakarta, Logos Discourse Science, 2003), Muslim Intellectual Essays and Islamic Education, Logos, Jakarta, Logos, 1999, Islamic Tradition and Modernization Education Towards the New Millennium, Jakarta, Logos, 1999, Theological Themes in Indonesia, Jakarta, Paramadina, 1999, New National Education Paradigm, Jakarta , Kompas, 2002, Reformist Islam: Intellectual and Movement Dynamics, Jakarta, Rajagrafindo Persada, 1999, Towards Civil Society, Bandung, Rosdakarya, 2000, Theological Themes in Indonesia, Jakarta, Paramadina, 1999, New Conflicts Between Civilizations: Globalization, Radicalism, and Plurality, Jakarta, Rajagrafindo Persada, 2002, Reaching Solidarity: Thesis between Democracy, Fundamentalism, and Humanism, Jakarta, Panjimas, 2002, Thousand Month Night: Devotionals 30 Ramadan Day, Jakarta, Erlangga, 2005, Middle East Ulama Network and Archipelago Islands XVII \& XVIII Century Roots of Renewing Indonesian Islam, Jakarta, Kencana, 2007.IAIN in the Middle of New College Paradigms, in the book: Problems and Prospects of IAIN Anthology of Higher Education Islam, Jakarta, Directorate of PTAI Development Director General of Institutional Development of Islamic Religion of the Ministry of Religion, 2000, "Sempalan" Group in PTU Students: SocioHistorical Anatomy, in the book: Dynamics of Islamic Thought in Universities, Jakarta, Logos, 1999, Islamic Education in Globalization era: Opportunities and Challenges, in the book: They Talk about Islamic Education A Potpourri, Jakarta, Rajawali Press, 2009. Building Democratic Civilization Into the New Indonesian Political Culture in Ninok Leksono (Ed), Indonesia XXI Century, Jakarta, Kompas, 2000.

\section{Thought of Azyumardi Azra's Renewal in Islamic Higher Education (PTKI) Scientific Development-Based}

According to Azra, in principle, the concept of Islamic education is what is called the monotheism paradigm or paradigm of tawhid. In this case, the paradigm of monotheism does not mean that it merely imposes God, but integrates all aspects, all views and aspects of life in our system and social field. ${ }^{16}$ According to Azra, epistemologically the knowledge comes from Allah, both the sciences qur'niyyah and the kauniyyah sciences. ${ }^{17}$ In the monotheistic paradigm, that all sciences are inspired and based on the teachings of the Quran and the Sunnah, regardless of the conclusions, they are categorized as Islamic studies. ${ }^{18}$ Azra argues that Islam as a universal religion and applies throughout the ages not only regulates afterlife, but also world affairs. Likewise, Islam governs the sciences relating to relations with God, and the sciences related to worldliness. Islam regulates its integrity in an integrated manner.

It can be called religious knowledge if it also regulates the doctrine of how good and civilized life in this world and what is actually called general science is really needed in order to connect with God. ${ }^{19}$

\section{Science Integration at PTKI}

Azra stated that as far as science is concerned, the latest challenges of Muslims are two things. First, the sciences which are separated from spiritual and ethical values are in some respects forbidden even for the future of humanity and the universe. Such knowledge must be muted with religious and spiritual values so as these sciences can bring full benefits to mankind and the universe. Second, the marginality of the sciences called "religious sciences". The challenge here is that to bring the sciences into the mainstream of Islamic perspective as a whole. Reconciliation and reintegration between the two scientific groups-the sciences originating from al-âyah al-qur'âniyyah and those originating from al-âyah kauniyyah-means returning to the transcendent unity of all science ${ }^{20}$. Thus, it

\footnotetext{
${ }^{16}$ Azyumardi Azra, Paradigma Baru Pendidikan Nasional Rekonstruksi dan Demokratisasi, (Jakarta: Kompas, 2002), p.127

${ }^{17}$ Interview, November 17, 2015

${ }^{18}$ Muqowim, Genealogi Intelektual Saintis Muslim: Sebuah Kajian tentang Pola Pengembangan Sains dalam Islam pada Periode 'Abbasiyyah, (Jakarta: Kementerian Agama, 2012), p. 406

19 Azyumardi Azra, Kata Pengantar Rektor UIN Syarif Hidayatullah Jakarta dalam Abuddin Nata, dkk, Integrasi Ilmu Agama dan Ilmu Umum, (Jakarta: Rajawali Press, 2003), p. viii

${ }_{20}$ Azyumardi Azra,Reintegrasi Ilmu-ilmu dalamBagir, dkk, (Ed) Abidin Zainal, Integrasi Ilmu dan Agama Interpretasi dan Aksi, (Bandung: Mizan, 2005), p.211
} 
is necessary to reformulate or reformulate the Islamic sciences which can unite the sciences that originate from the sources of qur'âniyyah and kauniyyah.

Azra revealed that reformulation of Islamic sciences is greatly important. In fact, not only that, but also related to the reformulation of the substance of the sciences which was then put back into the embrace of Islamic sciences. The general sciences are embraced back in reconciled into the Islamic sciences. Azra added that the scientific content is not enough to only be given the emblem of Islam, but also must be given a comprehensive and comprehensive Islamic color. The religious sciences are still important, but do not forget that the exact sciences are also significantly important. ${ }^{21}$ According to Azra, the cultivation of integrated sciences in the Islamic world clearly depends on an education system that allows the transmission and implantation of science in all its forms in an integrated and holistic manner. The Islamic education system should emphasize all religious sciences while also covering all forms of science and science. ${ }^{22}$

Azra stated that at present there have been many efforts done by experts to search the reasons why science and religion show dichotomous and unfriendly conditions. One of the findings is by integrating these sciences with the Islamic teaching approach ${ }^{23}$. The transformation of IAIN into UIN is basically a manifestation of the redefinition of Islamic studies with an integrative paradigm. With this paradigm, the pattern of relations between science and religion follows an integrative model, both at the level of ontology, epistemology, and axiology ${ }^{24}$. UIN Jakarta popularized scientific renewal with the term reintegration of science.

\section{Renewal of the State Islamic Institute "With Wider Mandate"}

IAIN Jakarta is one of the oldest IAINs in Indonesia, located in the capital city of Jakarta

\footnotetext{
${ }^{21}$ Azyumardi Azra, Paradigma Baru Pendidikan ..., p.124

${ }^{22}$ Azyumardi Azra, Reintegrasi Ilmu-ilmu..., p. 221

23 Azyumardi Azra, Kata Pengantar Rektor UIN Syarif Hidayatullah Jakarta..., p. viii

${ }^{24}$ Muqowim, Genealogi Intelektual..., p. 406
}

and occupies a unique and strategic position. It is not only a "Window of Islam in Indonesia", but also a symbol of the progress of national development, especially development in the socioreligious field. In an effort to integrate general science and religious sciences, this institution began to develop itself with the concept of IAIN with a broader mandate (IAIN with Wider Mandate) towards the establishment of the State Islamic University.The initial steps of this conversion began to intensify during Azra's leadership with the opening of the Department of Psychology and Mathematics Education

at the Tarbiyah Faculty, as well as the Islamic Economics and Banking Department at the Sharia Faculty in the 1998/1999 academic year ${ }^{25}$. Azra revealed that she was the prime figure who put forward the term with wider mandate in scientific development at IAIN in order to prepare to become a university ${ }^{26}$ as stated by Abuddin Nata. ${ }^{27}$

According to Azra, the alternative IAIN with wider mandate is more realistic in the framework of preparing infrastructure, facilities and resources. In accordance with the concept and framework of "IAIN with wider mandate", IAIN Jakarta will always develop general departments, especially exact sciences, which in the next stage are upgraded to faculties. At the same time, since 1998/1999, IAIN Jakarta began giving priority to the recruitment and appointment of prospective lecturers in accordance with the framework and concept of the IAIN with that broader mandate. ${ }^{28}$ Azra stated that by considering the various constraints that exist, the importance of Islam as the core of all knowledge, and historical considerations, IAIN Jakarta chose this alternative IAIN with a broader mandate. ${ }^{29}$

25 Tim Penyusunan Buku Pedoman Akademik UIN Syarif Hidayatullah Jakarta Tahun 2015, Pedoman Akademik Program Strata 1 Universitas Islam Negeri Syarif Hidayatullah Jakarta 2015/2016, (Jakarta: Biro Akademik, Kemahasiswaan dan Kerjasama UIN Syarif Hidayatullah Jakarta: 2015), p. 8

${ }^{26}$ Interview with Azyumardi Azra at Pascasarjana IAIN Bukitinggi, September 17, 2015.

${ }^{27}$ Interview with Abuddin Nata at Grand Malindo Hotel Bukittinggi, November 13, 2015. p. 40

${ }^{28}$ Azyumardi Azra, Paradigma Baru Pendidikan Nasional....,

29 Azyumardi Azra, IAIN di Tengah Paradigma Baru Perguruan Tinggi, in Komaruddin Hidayat and Hendri Prasetyo 
According to Azra, to achieve the goals of IAIN as a university or IAIN with a mandate to be expanded, IAIN Jakarta cooperates with Al-Azhar University Cairo Egypt. According to him, the work was to elevate Islamic sciences. Later, the alumni obtain a degree from Al-Azhar University and from IAIN. This is a dual degree program. Azra stated that the challenges were complex; in addition to developing Islamic sciences, IAIN Jakarta also developed sciences which have been called by the IAIN group itself, but significantly needed for the development of Muslims. IAIN will develop faculties and departments of exact sciences which are the basis of technological development. So, IAIN will develop the Faculty of MIPA and polytechnic programs. So far, according to Azra, these fields are greatly alarming. The point of view, the fields of science and technology that are strategic for the future such as computer technology are controlled by non-Muslims ${ }^{30}$.

New departments or programs are to realize the institute program called "IAIN with an expanded mandate". So, its mandate is not only in the field of religious sciences, but also in the fields of exact sciences and other natural sciences. The mandate is expended more for the long term plan to go towards UIN. Departments such as the Mathematics and Natural Sciences Department will in time be consolidated into separate faculties; from the Tarbiyah Faculty to the MIPA Faculty. According to Azra, for IAIN Jakarta, it actually did not open a new department, but a study program. IAIN Jakarta opened the new study program which would later be developed into departments and faculties. The opening of new programs at IAIN is actually quite conservative; not just open all the programs or majors in mind. The opening of the program or department is based on several rational considerations and feasibility ${ }^{31}$. At the time when IAIN Jakarta implemented the concept of IAIN with a broader mandate (IAIN with Wider

(Ed), Problem dan Prospek IAIN: Antologi Pendidikan Tinggi Islam, (Jakarta: Direktorat Pembinaan PTAI Dirjen Bimbaga Islam, 2000), p.17

$3^{\circ}$ Azyumardi Azra, Islam Substantif, (Jakarta: Mizan, 2000)., p.257

${ }^{31}$ Azyumardi Azra, Islam Substantif..., pp. 433-434
Mandate) it opened 12 general study programs, all of which received operational permits from the Director General of Higher Education of the Ministry of Education and Director General of the Ministry of Religion. With this permit, the status of this study program is the same as the status of general study programs in various Universities under the auspices of the Ministry of Education-now Kemenristek Dikti. ${ }^{32}$ Azra is a figure who popularized IAIN with Wider Mandate, as a form of renewal carried out in PTKI's scientific development.

\section{Transformation of IAIN into UIN}

According to Azra, the presence of UIN allows 'reintegration' among the sciences originating from the Qur'âniyyah verses on one side with the sciences sourced from the kauniyyah verses on the other side. It has been too long-precisely since the post-Baghdad period-there has been a sharp dichotomy between these two forms of Ilâhiyah verses. As a result, it is clear, Muslims are left behind in kauniyyah science compared to other nations. In fact, the perfection of practicing Islam requires not only the Qur'âniyyah sciences, but also the kauniyyah sciences. The welfare of the Muslim world cannot be achieved properly without the mastery of the kauniyyah sciences so that epistemologically and in reality and praxis of Islamic life and Muslims, the reintegration of the sciences of Qur'âniyyah and kauniyyah is a historical necessity and an urgent need. Delaying reintegration is only preserving the marginalization and defeat of the nation's people. ${ }^{33}$

According to Azra, in separating UIN, some of the nation's children still need to do tafaqquh fi ad-dîn or tafaqquh fi at-tafsîr-really fiqh, or related interpretations and other sciences, there must also be a nation child who does tafaqquh fi ath-thib or tafaqquh fi al-kimiyya-persevere in sexual sciences or other such sciences. So, there is a distribution of experts in various fields that are needed and needed. Azra revealed that Islam covered various kinds of knowledge for

\footnotetext{
${ }^{32}$ Abuddin Nata,Tokoh-tokoh Pembaharuan..., p. 402

${ }_{33}$ Azyumardi Azra, Paradigma Pendidikan....,p. 295
} 
the benefit of self, society, nation and state. Special and developing neglect can make the atmosphere of underdevelopment unable to respond to growing needs and challenges. ${ }^{34}$

According to Azra, the change of IAIN to be a university aims to reaffirm that the Islamic sciences are greatly broad, including general sciences that are beneficial to the benefit of humanity which contributes greatly to civilization. Therefore, the change of IAIN to be a university is a strategic step to overcome the dichotomy of the religious sciences with the general sciences. With this change, reintegration can be carried out between the two scientific fields. ${ }^{35}$ However, Azra added that the reintegration of the two science groups at the university level was not easy. The people and the nation must wait for the coming 1998 reforms which opened up great opportunities and blessings for the transformation of IAIN to UIN, which was realized for the first time on May 20, 2002 when Jakarta's IAIN Syarif Hidayatullah changed officially to UIN Syarif Hidayatullah Jakarta which allowed the reintegration of both of the science groups. ${ }^{36}$ The change of Syarif Hidayatullah IAIN Jakarta became the Syarif Hidayatullah UIN Jakarta based on the Republic of Indonesia's Presidential Decree Number 31 of 2002. According to Azra, each UIN can develop the distinction of the integration of their respective knowledge. So far, the difference, for example, can be seen from UIN Jakarta which is based on the reintegration of sciences originating from the verses of Qur'aniyyah with the sciences that develop from the verses of kauniyyah. Whereas UIN Yogyakarta developed integration through interrelation and interconnection of science which was reflected in the 'spider web of science'. Then, UIN Malang based the concept of integration on the 'scientific tree' along with branches, branches and branches. ${ }^{37}$

34 Azyumardi Azra, Paradigma Baru PTAI/PTKI; Menuju Renaisans Peradaban Islam, Paper presented at the PAI Postgraduate Program IAIN Bukittinggi, 9 June 2015, p. 3

35 Andina Dwifatma, Cerita Azra: Biografi Cendikiawan Muslim..., p. 77

${ }^{36}$ Azyumardi Azra, Paradigma Baru PTAI/PTKI..., p.4

37 Kepres RI No. 31 Tahun 2002 tentang Perubahan IAIN Syarif Hidayatullah Jakarta menjadi Universitas Islam Negeri Syarif Hidayatullah Jakarta
Azra said that UIN Jakarta directed itself to scientific integration as mentioned above. This integration is based on faith, knowledge, and good deeds. The paradigm of scientific integration is the basis for the development of universities so that they can make a significant contribution to the progress of the nation. ${ }^{38}$ Azra wants UIN to place more emphasis on the reintegration of the verses of Qur'aniyyah, revelations that come from Allah, and the verses of kauniyyah which are signs found in the universe. ${ }^{39}$

According to Azra, each of the other UINs must also have their own integration paradigms for distinctive development. The existence of differences in each UIN is important for strengthening institutional identities that are in certain localities that have reality, challenges and needs that are relatively different from each other. With the differences in each UIN, the nation's children get a variety of choices that can be taken according to their scientific background, needs and challenges. Azra revealed that on the other side, the realization of UIN is a further stage of mainstreaming Islamic higher education institutions. Mainstreaming had actually begun when the 1989 National Education System Act recognized the madrasas as equivalent or the same as public schools. In this regard, the emergence of UIN is a logical consequence of mainstreaming that has taken place at the madrasa level. According to Azra, with the mainstreaming of Islamic higher education, there was an opportunity for UIN to compete with other universities in the country; not only to achieve the expectations of academic excellence, but also at the same time social expectations-the hopes of the wider community that PTKI can play a wider role and contribute more to the progress of the nation and state. The opportunity in that direction is now wide open; much depends on the UIN academics to more seriously change the challenges and expectations into opportunities and reality. One of them, as often stated by Prof. Dr. A Malik

\footnotetext{
${ }^{38}$ Azyumardi Azra, Reintegrasi Ilmu-ilmu...,p.11

39 Andina Dwifatma,Cerita Azra: Biografi Cendikiawan Muslim..., p. 96
} 
Fadjar, while serving as Minister of National Education, changed the mentality of 'institute' to be the mentality of the university. ${ }^{40}$

Abuddin Nata stated that the scientific reintegration efforts carried out at UIN Jakarta were with several efforts, namely through Islamic study courses. Islamic study courses are given to all majors/study programs in order to develop Islamic studies in various perspectives, both economics, health, science and so on. In addition, reintegration is also carried out by providing religious reinforcement to general faculties. ${ }^{41}$ Suwito revealed that the stages carried out in scientific reintegration at UIN Jakarta were to carry out five stages, namely through historical content, theoretical content, case content, Islamic content, and content science. ${ }^{42}$ Thought that integrates religious sciences with general sciences is a mission that is expected to occur from changes in IAIN to UIN. The integration of science at UIN Jakarta was popularized by the term reintegration of science.

Azra is one of the leaders who is able to bring institutional renewal of the Religious College by transforming IAIN into UIN. This renewal became the beginning and at the same time encouraged other STAIN / IAIN to transform into UIN so that PTKI institutions became stronger and able to be competitive with other universities.

\section{Analysis of Azyumardi Azra's Thought Renewal in the Context of Islamic Higher Education Development}

Azra is a figure who is not only able to think theoretically but also applies it to a reality. This can be seen from the success achieved both while leading intra and extra campus organizations, as well as Rector of IAIN Jakarta (1998-2002) and Rector of UIN Jakarta (20022006). ${ }^{43}$ Azra consistently brings the university he leads to the center of the battle between state universities. ${ }^{44}$

\footnotetext{
${ }^{40}$ Azyumardi Azra, Paradigma Baru PTAI/PTKI...,.p. 5

${ }^{41}$ Interview, November 13, 2015

${ }^{42}$ Interview, May 27, 2016

${ }^{43}$ Abuddin Nata, Tokoh-tokoh Pembaharuan..., p. 414

44 Andina Dwifatma,Cerita Azra: Biografi Cendikiawan Muslim..., p. 228
}

The paradigm of integration of science in UIN Jakarta ontologically can be seen from four functions, namely cognitive, constitutive, communicative, and effective. Cognitively, the integration of science in UIN Jakarta means that what is real (beneficial) to humans and not contrary to the laws of divinity. Constitutively, the integration of science is to make it one type of science which is as an inseparable part of other types of knowledge. Communicatively, the integration of science is open and opened to interact or only exists side by side between types of knowledge. An open and opened attitude presupposes the attitude of UIN Jakarta about the science that accepts the possibility of the existence of "sharing" essence or technical production of science. Finally, the integration of science is not assumed to cause tension, but it is better to encourage the effectiveness of the use of science itself by maintaining the position of humans as producers and users of knowledge that utilize the surrounding environment while still appreciating different types of science. ${ }^{45}$

Epistemologically, the paradigm of integration of science at UIN Jakarta is built using the mindset of science and rational thought patterns. The epistemological mindset of science is "anthropo-centric" that is valuefree while the rational mindset is more "theocentric". That is, various theories of social, political, economic and cultural sciences must be built on the foundation of revelation. From this there is really no conflict between the "anthropo-centric" epistemology and the "theocentric" epistemology. Both have their own proportions. In this context, UIN Jakarta can build academic distinction by adopting a mindset of science and a rational mindset. That is, UIN can develop value-free science through various experimental studies which are then developed into appropriate technologies. At the same time, UIN can also develop "general" studies which are built on the foundation of divine epistemology (based on revelation). Thus, UIN can develop sciences based on "divine epistemology". More

${ }^{45}$ Kusmana, (Ed), Integrasi Keilmuan UIN Syarif Hidayatullah Jakarta Menuju Universitas Riset, (Jakarta: UIN Jakarta Press, 2006), pp. 70-71 
specifically, for UIN Jakarta the revelation will be world view in understanding and making decisions on empirical facts, even if not labeled Islam, such as the economy, agribusiness, and others. ${ }^{46}$ In the context of UIN Jakarta, the diversity of values (qimah) which is the goal of Muslim scientists, whether in the form of material, humanity, akhlaqiyyah, or purely contentment leads to one very important thing, namely the pleasure of Allah Swt. Therefore, the integration of axiological science in UIN Jakarta is the integration between the acquisition of benefits with a spiritual awareness; or between professionalism, honesty, objectivity by worshiping Allah Swt. In addition, the use of scientific products will be more directed towards achieving the pleasure of Allah. ${ }^{47}$

One effort to integrate knowledge at UIN Jakarta is to bring up Islamic courses in general majors/study programs, for example medicine courses in Islam at the Faculty of Medicine and Health Sciences. This course explores medical material in Islam, both ontologically, epistemologically and axiologically from Islam, while also taking theories from other than Islam, as long as it does not conflict with revelation.

According to Nurlena, et al, the concept of scientific integration developed at UIN in Indonesia, in fact, actually refers to the same estuary, namely the elimination of the dichotomy between the truth of revelation and the truth of science. In other words, scientific integration aims to combine the truth of revelation with the truth of science that is implemented in the education process. However, the concept of scientific integration in each UIN has editorial diversity and very contextual elaboration with the environment of each UIN. ${ }^{4}$ Furthermore, Nurlena et al. stated that substantively, all six State Islamic Universities (UIN), including Jakarta, Yogyakarta, Malang, Makassar, Bandung and Pekanbaru, have the same concept of scientific integration and have the same goal, namely

\footnotetext{
${ }^{46}$ Kusmana, (Ed), Integrasi Keilmuan UIN..., p. 87

${ }^{47}$ Kusmana, (Ed), Integrasi Keilmuan UIN..., p. 97

48 Nurlena, dkk, "Integrasi Keilmuan dalam Pengembangan Kurikulum di UIN se-Indonesia: Evaluasi Penerapan Integrasi Keilmuan UIN dalam Kurikulum dan Proses Pembelajaran", Jakarta: TARBIYA Vol. 1, No. 1, Juni 2014, p. 27
}

eliminating the scientific dichotomy between religious sciences and secular science. 49

Scientific and institutional development in Islamic religious colleges (PTKI) has begun to be interest to the public. This can be seen in several departments and study programs at UIN which have become the first choice for prospective students, even those who are interested are increasingly increasing. Improved infrastructure continues to be improved. UIN Jakarta as one of the Islamic religious colleges in Indonesia already has adequate facilities with modern designs, including libraries. Changes in IAIN / STAIN to UIN were pioneered by Islamic thinkers in Indonesia, including Azra who had the same mission, namely to eliminate the scientific dichotomy by building an integrative scientific paradigm. Scientific development with an integrative paradigm requires the need for institutional change from the form of IAIN/STAIN to become a university. With this form of university institution, it will be able to develop science integratively.

The impact and benefits of scientific reform and institutional PTKI can now be seen and felt by Muslims themselves, especially and the Indonesian people in general. This scientific and institutional development needs to be refined from its various shortcomings, so that in the future PTKI can compete with other universities. Thus, it can be understood that the context of scientific and institutional renewal in PTKI according to Azra's thinking is to have the same mission, namely to eliminate the scientific dichotomy in scientific development and to develop an integrative scientific paradigm. Scientific development with an integrative paradigm requires the need for institutional changes from the form of IAIN/ STAIN to UIN so that the institutions in the form of UIN provide access, opportunities and greater roles for PKTI in scientific and institutional development.

\section{Conclusion}

The renewal of the scientific knowledge of Islamic religious colleges (PTKI) according

${ }^{49}$ Nurlena, dkk, Integrasi Keilmuan dalam Pengembangan..., 
to Azyumardi Azra's thought is that the basis and development of science must refer to the paradigm of tauhid which comes from revelation (Quran and hadith), both the qur'âniyyah and kauniyyah sciences. PTKI's renewal is the concept of IAIN with a broader mandate (IAIN with Wider Mandate) towards the formation of UIN, namely as an effort to integrate general science and religious knowledge and transform it into a State Islamic University (UIN). This enables the role of PTKI in the academic world of science and at the same time to contribute to the overall progress of the people and nation of Indonesia.

The context of scientific and institutional renewal in Islamic religious colleges in the style of Azyumarid Azra's thought has the same mission, namely to eliminate the scientific dichotomy in the scientific development of PTKI by developing an integrative scientific paradigm. Scientific development with an integrative paradigm requires the need for institutional changes from the form of IAIN / STAIN to UIN.

\section{References}

Abdullah, M. Amin, Islamic Studies di Perguruan Tinggi: Pendekatan Integratif-Interkonektif, Yogyakarta: Pustaka Pelajar, 2012.

Al Munawar, Said Agil Husin, Sambutan Meteri Agama Dalam Acara Dies Natalis Ke-45/Lustrum Ke-9 IAIN/UIN Syarif Hidayatullah Jakarta, 8 Juni 2002, dalam Kusmana dan Yudhi Munadi, (Ed), Proses Perubahan IAIN Menjadi UIN Syarif Hidayatullah Jakarta, Jakarta: UIN Jakarta Press, 2002.

, Genealogi of Islamic Education: Roles In The Modernization Of Muslim Society, dalam Heritage Of Nusantara; International Journal Religoius Literature and Heritage, Vol. 4. No. 12015

, IAIN di Tengah Paradigma Baru Perguruan Tinggi, dalam Komaruddin Hidayat dan Hendri Prasetyo (Ed), Problem dan Prospek IAIN: Antologi Pendidikan Tinggi Islam, Jakarta: Direktorat Pembinaan PTAI Dirjen Bimbaga Islam, 2000.

, Islam Nusantara: Jaringan Global dan Lokal, Bandung: Mizan, 2002.

, Kata Pengantar Rektor UIN Syarif Hidayatullah
Jakarta dalam Abuddin Nata, dkk, Integrasi Ilmu Agama dan Ilmu Umum, Jakarta: Rajawali Press, 2003.

, Kata Pengantar Rektor UIN Syarif Hidayatullah Jakarta dalam Abuddin Nata, dkk, Integrasi Ilmu Agama dan Ilmu Umum, Jakarta: Rajawali Press, 2003.

, Konflik Baru Antar Peradaban: Globalisasi, Radikalisme \& Pluralitas, Jakarta: Rajawali Press, 2002.

, Konteks Berteologi di Indonesia Pengalaman Islam, Jakarta: Paramadhina, 1999.

, Membangun Integrasi Ilmu, Iman, Amal dan Akhlak, Sambutan Pidato Peresmian

IAIN Syarif Hidayatullah menjadi UIN SYarif Hidayatullah, Jakarta, 8 Juni 2002) dalam Kusmana dan Yudhi Munadi, (Ed), Proses Perubahan IAIN Menjadi UIN Syarif Hidayatullah Jakarta, Jakarta: UIN Jakarta Press, 2002.

- Paradigma Baru Pendidikan Nasional Rekonstruksi dan Demokratisasi, Jakarta: Kompas, 2002.

, Paradigma Baru PTAI/PTKI; Menuju Renaisans

Peradaban Islam, Makalah disampaikan pada Kuliah Umum Program Studi S2 PAI Pascasarjana IAIN Bukittinggi, Selasa 9 Juni 2015

, Pendidikan Islam dalam Sistem Pendidikan Nasional di Indonesia (Edisi Revisi), Jakarta: Kencana, 2012.

, Pendidikan Islam Tradisi dan Modernisasi di Tengah Tantangan Milenium III, Jakarta: Logos, 2012.

, Rekonstruksi Kritis Ilmu dan Pendidikan Islam, dalam Abdul Munir Mulkhan, dkk, Rekonstruksi Pendidikan dan Tradisi Pesantren: Religiusitas Iptek, Yokyakarta: Pustaka Pelajar, 1998.

, Transformasi Islam Paradigmatik dalam Dinamika Global, dalam Nurus Shalihin, dkk (Ed), Mozaik Islam Nusantara: Seri Agama, Budaya, Ilmu Pengetahuan dan Negara, Padang: IAIN Imam Bonjol Press, 2014. , Visi IAIN di Tengah Paradigma Baru Perguruan Tinggi, dalam Abdul Halim (Ed), Teologi Islam Rasional; Apresiasi Terhadap Wacana dan Praksis Harun Nasution, Jakarta: Ciputat Press, 2005. 
Visi IAIN di Tengah Paradigma Baru Perguruan Tinggi, dalam Abdul Halim (Ed), Teologi Islam Rasional; Apresiasi Terhadap Wacana dan Praksis Harun Nasution, Jakarta: Ciputat Press, 2005.

Bagir, (Ed), Zainal Abidin, Integrasi Ilmu dan Agama: Interpretasi dan Aksi, Bandung: Mizan, 2005.

Brodjonegoro, dkk,Satryo Seomantri, Implementasi Paradigma Baru Pendidikan Tinggi, dalam Fasli Jalal dan Dedi Supriadi, Reformasi Pendidikan dalam Konteks Otonomi Daerah, Yokgakrta: Adicita Karya Nusa, 2001.

Dwifatma, Andina, Cerita Azra; Biografi Cendekiawan Muslim Azyumardi Azra, Jakarta: Airlangga, 2011.

Furchan, Arif, dan Agus Maimun, Studi Tokoh: Metode Penelitian Mengenai Tokoh, Yokyakarta: Pustaka Pelajar, 2005.

Husaini, Adian, Virus Liberalisme di Perguruan Tinggi Islam, Jakarta: Gema Insani Press, 2009. , Liberalisasi di Indonesia: Fakta, Gagasan, Kritik, dan Solusinya, Jakarta: Gema Insani Press, 2015.

Jamhari, IAIN Jakarta: Konteks Sejarah, Masa Kini, dan Prospek ke Depan dalam Kusmana dan Yudhi Munadi, (Ed), Proses Perubahan IAIN Menjadi UIN Syarif Hidayatullah Jakarta, Jakarta: UIN Jakarta Press, 2002.

Kepres RI No. 31 Tahun 2002 tentang Perubahan IAIN Syarif Hidayatullah Jakarta menjadi Universitas Islam Negeri Syarif Hidayatullah Jakarta

Kusmana, (Ed), Integrasi Keilmuan UIN Syarif Hidayatullah Jakarta Menuju Universitas Riset, Jakarta: UIN Jakarta Press, 2006.

Mahzar, Armahedi, Merumuskan Paradigma Sains dan Teknologi Islam: Revolusi Integralisme Islam, Bandung: Mizan, 2004.

Muhaimin, Pemikiran dan Aktualisasi Pengembangan Pendidikan Islam, Jakarta: Rajawali Press, 2011. Muqowim, Genealogi Intelektual Saintis Muslim: Sebuah Kajian tentang Pola Pengembangan Sains dalam Islam pada Periode 'Abbasiyyah, Jakarta: Kementerian Agama, 2012.

Nata, Abuddin, dkk, Integrasi Ilmu Agama dan Ilmu Umum, Jakarta: Rajawali Press, 2003.

Nata, Abuddin, Tokoh-tokoh Pembaharuan Pendidikan Islam di Indonesia, Jakarta: Rajawali Press, 2005.
Natsir (ed), Nanat Fatah, Strategi Pendidikan: Upaya Memahami Wahyu dan Ilmu, Yogyakarta: Pustaka Pelajar, 2010.

Nurlena, dkk, Integrasi Keilmuan dalam Pengembangan Kurikulum di UIN se-Indonesia: Evaluasi Penerapan Integrasi Keilmuan UIN dalam Kurikulum dan Proses Pembelajaran, Jakarta: TARBIYA Vol. 1, No. 1, Juni 2014.

Riyanto, Waryani Fajar, Integrasi-Intekkoneksi Keilmuan: Biografi Intelektual M. Amin Abdullah (1953-...) Person, Knowledge, and Institution, Yokyakarta: SUKA Press, 2013.

Sambutan Menteri Pendidikan Nasional RI Prof.

Dr. H. Malik Fadjar, M.Sc pada Upacara Dies Natalis Ke-45/Lustrum Ke-9 IAIN dan Peresmian UIN Syarif Hidayatullah Jakarta, Sabtu, 08 Juni 2002

Suprayogo, Imam, Paradigma Pengembangan Keilmuan Islam: Perspektif UIN Malang, Malang: UIN Press, 2006.

Suprayogo, Membangun Perguruan Tinggi Islam Bereputasi Internasional: Laporan Pertanggungjawaban Rektor UIN Maulana Malik Ibrahim Periode 2009-2013, Malang: UIN Malang, 2013. , Memelihara Sangkar Ilmu: Refleksi Pemikiran dan Pengembangan UIN Malang, Malang: UIN Malang Press, 2006.

Sutrisno, Pembaharuan dan Pengembangan Pendidikan Islam: Membentuk Insan Kamil yang Sukses dan Berkualitas, Yokyakarta: Fadilatama, 2011.

Suwito, Mungkin Segalanya Mungkin: Otobiografi Suwito, Tangerang Selatan: YPM, 2016.

Syamsuddin, Ach. Maimun, Integrasi Multidimensi Agama dan Sains: Analisis Sains Islam Al-Attas dan Mehdi Golshani, Jogjakarta: IRCiSoD, 2012.

Taher, Tarmizi, Membumikan Ajaran Ketuhanan: Agama dalam Transformasi Bangsa, Jakarta: Hikmah, 2003.

Tholkhan, Imam, dan Ahmad Barizi, Membuka Jendela Pendidikan: Mengurai Tradisi dan Integrasi Keilmuan Pendidikan Islam, Jakarta: Rajawali Press, 2004.

Tim Penyusunan Buku Pedoman Akademik UIN Syarif Hidayatullah Jakarta Tahun 2015, Pedoman Akademik Program Strata 1 Universitas Islam Negeri Syarif Hidayatullah 
MADANIA Vol. 22, No. 2, Desember 2018

Jakarta 2015/2016, Jakarta: Biro Akademik, Kemahasiswaan dan Kerjasama UIN Syarif Hidayatullah Jakarta: 2015.
Yatim, Badri, dan Hamid Nasuhi, (Ed), Membangun Pusat Keunggulan Studi Islam; Sejarah dan Profil Pimpinan IAIN Jakarta 1957-2002), Jakarta: IAIN Jakarta Press, 2002. 